Olausson, E., 1961. Studies of deep-sea cores: Rept: Swedish Deep-Sea Exped., v. 8, p. 337-391.

Potoniè, R., 1937. Die nomenklature der unterwasser-ablagerungen: Jahrb. Preuss. Geol. Landesanstalt, v. 58, p. 426428.

Robert, C., 1974. Contribution à l'étude de la sédimentation argileuse en Méditerranée orientale. Thèse 3ème cycle, Aix-Marseille II, dact., p. 86.

Robert, C. and Chamley, H., 1974. Gypse et sapropels profonds de Méditerranée orientale; C. R. Acad. Sci., Paris, Ser. D, v. 278 , p. 843-846.

Ryan, W. B. F., 1972. Stratigraphy of late Quaternary sediments in the eastern Mediterranean. In Stanley, D. J., (Ed.), The Mediterranean Sea: Strasbourg, Virginia (Dowden, Hutchison and Ross), p. 419-176.

Ryan, W. B. F., Hsü, K. J., et al., 1973. Initial Reports of the Deep Sea Drilling Project, Volume 13: Washington (U.S. Government Printing Office).
Seibold, E., Müller, G., and Fesser, H., 1958. Chemische Untersuchungen eines Sapropels aus der mittleren Adria: Erdöl and Kohle, v. 5, p. 296-300. in preparation. Sapropel(ic) layers in meteor-cores from the eastern Mediterranean.

Sigl, W. and Müller, J., in press. Identification and correlation of stagnation layers in cores from the eastern Mediterranean Sea: Verb. Reun. Proc., Monaco.

Trask, P. D., 1939. Organic content of Recent Marine sediments. In Trask, P. D. (Ed.), Recent marine sediments: London (Thomas Murby \& Co.), p. 428-453.

Wasmund, E., 1930. Bitumen, sapropel und gyttja. Geol. Foren. Förhandl., v. 52, Stockholm, p. 315-350.

Wenzlow, B. and Sigl, W., in preparation. Organic geochemistry of Mediterranean sapropels and some paleoenvironmental implications.

\title{
13.3 ORGANIC GEOCHEMISTRY OF SOME NEOGENE CORES FROM SITES 374, 375, 377, AND 378: LEG 42A, EASTERN MEDITERRANEAN SEA
}

\author{
G. Deroo, J. P. Herbin, and J. Roucaché Institut Français du Petrole, 1 et 4 avenue de Bois Preau, \\ 92502 Rueil-Malmaison, France
}

\begin{abstract}
Two different types of organic matter were defined in eastern Mediterranean sediments of late Neogene age which were sampled from cores of the DSDP Leg 42A cruise.

Pyrolysis assay and chloroformic extraction were techniques that were used together with analysis of humic compounds and kerogen fraction. Organic matter from Messinian evaporitic levels of the Ionian Basin (Site 374) could be of marine origin. For the other Neogene samples taken from the Mediterranean Ridge Cleft (Site 377), the Cretan Basin (Site 378), and the Florence Rise (Site $375)$, the organic material mainly originated from continental sources. All the analyzed samples are immature but the samples of Serravallian age from the Florence Rise were the most evolved and had reached the stage of late diagenesis or early catagenesis. It is shown that rich organic black sediments (many of which are referred to as sapropels) may have a number of origins and inferred environments of deposition.
\end{abstract}

\section{INTRODUCTION}

The aim of this paper is to define the different types and the origin of the organic matter in eastern Mediterranean sediments of late Neogene age.

Since burial depths were low and the geological age of the sediments relatively young only minor evolution of hydrocarbons would be expected. Nevertheless geochemical analyses were performed to confirm this point.
A pyrolysis assay for hydrocarbon detection on raw material and some chloroform solvent extractions were first performed. They were useful to characterize ancient sediments. Then followed a study of the remaining insoluble organic fraction on some selected samples. The characterization of the latter is reached from the study of humic compounds on one hand and the kerogen fraction on the other. The elemental composition of kerogen, and the proportion of humic compounds in organic matter give valuable indications as 
to its origin; marine autochtonous versus continental detrital. Furthermore, humic compounds are well represented in immature sediments while kerogen fractions are present in both immature and mature materials.

\section{SAMPLING}

Thirty-two samples of some 10 grams each ( 5 to 20 g) were received from the cores of Sites $374,375,377$, and 378 drilled during the Leg $42 \mathrm{~A}$ of D.S.D.P. cruise in eastern Mediterranean Sea. They mainly belong to upper and middle Miocene while two have Pliocene ages (Figure 1) according to the shipboard report, 1975. Their updated stratigraphy and lithologic terminology are given on Table 1 .

\section{ANALYTICAL METHODS}

As they were received, the 32 samples were freeze dried. Then they were ground in an AUREC pulverizer (Grain size $\approx 90 \mu$ ). The successive analytical processes are schematized on Figure 2. Organic carbon was analyzed with a LECO apparatus. A pyrolysis assay is applied on raw samples as a method of source rock and maturation characterization (Espitalie et al., 1977). The method is deduced from kerogen experimental studies (Durand and Espitalie, 1973; Espitalié et al,

\section{EASTERN MEDITERRANEAN}

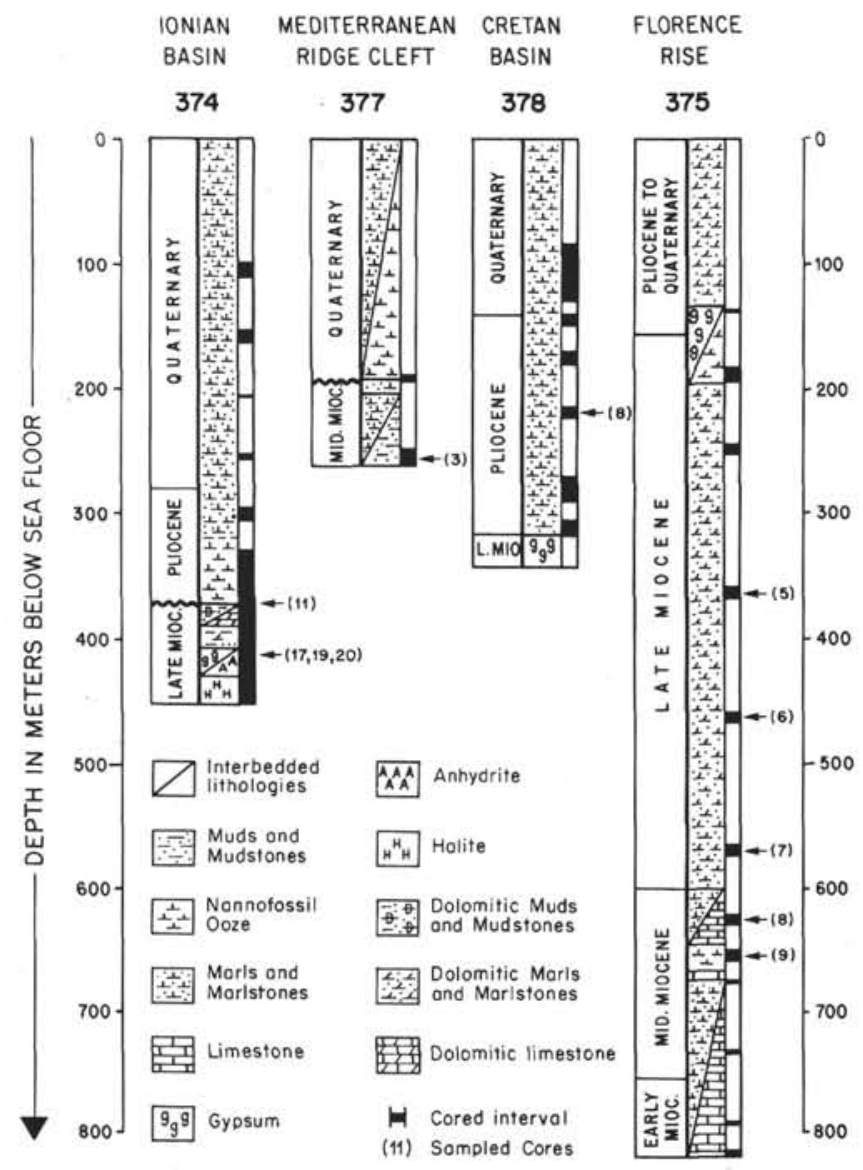

Figure 1. Stratigraphic location of sites and samples.
1973; Tissot et al, 1974). Equivalent parts of ground samples are extracted with chloroform and the extracts fractionated according to a method described in Huc et al. (1977). On the insoluble part of rock the total humic compounds are extracted and humic acids (H.A.) are separated from fulvic acids (F.A.) (Huc et al., in press). The new insoluble part corresponds to humin and the non-hydrolysable fraction is the kerogen (Durand et al., 1972; Robin et al., in press). Determination of organic carbon content from total humic compounds and from fulvic fraction is performed with a Carmnograph Wosthoff (MAJ) apparatus. Elemental analysis $(\mathrm{C}, \mathrm{H}, \mathrm{O}, \mathrm{N}, \mathrm{S}$ and $\mathrm{Fe}$ ) and ash content are measured on kerogen and calculated on a mineral-free basis.

\section{DETAILED RESULTS}

\section{Mineral Carbon (Table 1)}

There is a good agreement between the mineral carbon data for analyzed samples and the petrographic definition of series used in the cruise report. Samples of limestones from Site 374 close to the Miocene-Pliocene contact have some 70 percent of carbonates and the content is clearly low for the Messinian evaporite levels

TABLE 1

Location of Samples, Lithology and Age, and Carbon Data and Pyrolysis Temperatures

\begin{tabular}{|c|c|c|c|c|c|c|}
\hline \multirow[b]{3}{*}{$\begin{array}{c}\text { Sample } \\
\text { (Interval in } \mathrm{cm} \text { ) }\end{array}$} & \multirow{3}{*}{$\begin{array}{c}\text { Depth } \\
\text { Below } \\
\text { Sea } \\
\text { Floor } \\
(\mathrm{m})\end{array}$} & \multirow[b]{3}{*}{$\begin{array}{l}\text { Lithology } \\
\text { and Age }\end{array}$} & \multirow[b]{3}{*}{$\begin{array}{l}\mathrm{Ca} \mathrm{CO}_{3} \\
(\%)\end{array}$} & \multicolumn{2}{|c|}{$\begin{array}{c}\text { Organic } \\
\text { Carbon (\%) }\end{array}$} & \multirow{3}{*}{$\begin{array}{l}\text { Pyrol } \\
\text { ysis } \\
\text { Temper } \\
\text { ature } \\
\left({ }^{\circ} \mathrm{C}\right)\end{array}$} \\
\hline & & & & $\begin{array}{l}\text { Before } \\
\mathrm{HCCl}_{3}\end{array}$ & $\begin{array}{c}\text { After } \\
\mathrm{HCCl}_{3}\end{array}$ & \\
\hline & & & & $\begin{array}{c}\text { Extrac } \\
\text { tion }\end{array}$ & $\begin{array}{c}\text { Extrac } \\
\text { tion }\end{array}$ & \\
\hline \multicolumn{7}{|l|}{374} \\
\hline $11, \mathrm{CC}$ & 381.5 & Dolomite with & 68 & 2.08 & 1.95 & 432 \\
\hline $11, \mathrm{CC}$ & 381.5 & $\begin{array}{l}\text { sapropelitic layers } \\
\text { (early Pliocene) }\end{array}$ & s 71 & 1.83 & 1.91 & 439 \\
\hline $17-1,72-78$ & 411.8 & Dolomitic mud- & 25 & 5.57 & 4.66 & 430 \\
\hline $19-1,148-150$ & 419.5 & stone overlying & 34 & 2.22 & 1.91 & 427 \\
\hline $20-1,22$ & 420.2 & gypsum & 14 & 4.44 & 4.12 & 433 \\
\hline $20-1,25-28$ & 420.3 & (Messinian) & 12 & 4.14 & 3.50 & 433 \\
\hline \multicolumn{7}{|l|}{377} \\
\hline $3-2,60-65$ & 259.1 & $\begin{array}{l}\text { Mudstone (mid- } \\
\text { dle Miocene) }\end{array}$ & 16 & 0.71 & 0.70 & 428 \\
\hline \multicolumn{7}{|l|}{378} \\
\hline $8-2,26-32$ & 225.3 & $\begin{array}{l}\text { Nannofossil } \\
\text { marlstone (late } \\
\text { Pliocene) }\end{array}$ & 37 & 4.08 & 3.96 & 436 \\
\hline \multicolumn{7}{|l|}{375} \\
\hline $5-2,82-88$ & 362.3 & & 23 & 2.31 & 2.30 & 432 \\
\hline $5-3,02-04$ & 363 & & 30 & 1.18 & 1.18 & 434 \\
\hline $5-4,150$ & 364.5 & & 59 & 0.23 & 0.19 & \\
\hline $6-2,13-17$ & 462.6 & & 32 & 0.50 & 0.47 & \\
\hline $6-3,45-48$ & 464.4 & Marlstone & 26 & 4.35 & 4.31 & 412 \\
\hline $64,85-87$ & 466.3 & $\begin{array}{l}\text { Maristone } \\
\text { (Tortonian) }\end{array}$ & 30 & 0.53 & 0.47 & 422 \\
\hline $7-2,105-108$ & 567.5 & & 22 & 2.66 & 2.54 & 432 \\
\hline $7-2,138-140$ & 567.9 & & 21 & 0.44 & 0.46 & 434 \\
\hline $7-4,26-28$ & 569.8 & & 19 & 0.70 & 0.71 & 437 \\
\hline $7-6,26-30$ & 572.7 & & 22 & 0.45 & 0.43 & 440 \\
\hline $7-6,54-57$ & 573 & & 23 & 0.41 & 0.40 & \\
\hline $8-1,41-44$ & 622.4 & & 15 & 1.92 & 2.00 & 440 \\
\hline $8-2,110-113$ & 624.6 & & 10 & 0.18 & 0.22 & \\
\hline $8-3,55-57$ & 625.5 & & 8 & 0.52 & 0.48 & \\
\hline $8-3,128-130$ & 626.3 & & 31 & 0.40 & 0.40 & 434 \\
\hline $9-1,05-07$ & 650.5 & & 27 & 0.76 & 0.69 & 440 \\
\hline $9-1,102-106$ & 651.5 & Marlstone & 9 & 4.76 & 4.10 & 434 \\
\hline $9-2,139-142$ & 653.4 & (Serrayallian) & 28 & 0.68 & 0.62 & 444 \\
\hline $9-3,47-56$ & 654 & & 22 & 3.45 & 3.82 & 439 \\
\hline $9-3,53-57$ & 654 & & 23 & 1.07 & 0.97 & 424 \\
\hline $9-3,130-133$ & 654.8 & & 10 & 5.62 & 5.06 & 426 \\
\hline $9-4,16-20$ & 655.2 & & 23 & 3.04 & 3.15 & 426 \\
\hline $9-5,06-10$ & 656.6 & & 24 & 2.75 & 2.80 & 426 \\
\hline $9-6,24-28$ & 658.2 & & 27 & 0.36 & 0.36 & \\
\hline
\end{tabular}

Note: Updated using Site Report data, Chapters 2 to 8. 


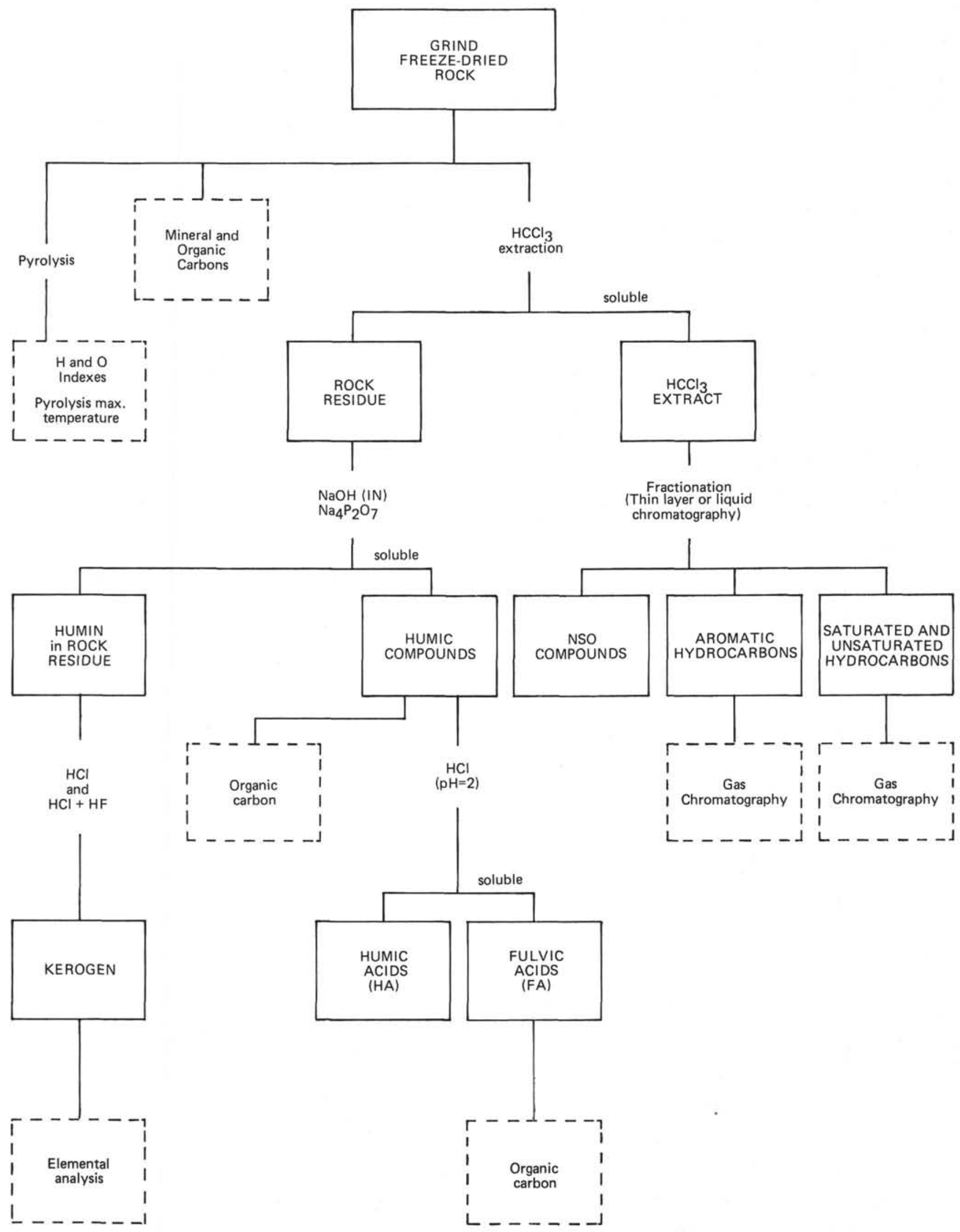

Figure 2. Schematic analytical procedures. 
with a 12 to 25 and 34 percent range. The only sample from the middle Miocene mudstones of Site 377 was 16 percent against 37 percent for the late Pliocene marlstone sample of Site 378. In Site 375 the Tortonian marlstones have a carbonate range between 19 to 32 and 59 percent. The content is somewhat lower in the Serravallian marlstones with an 8 to 31 percent range.

\section{Organic Carbon (Table 1)}

In Site 374 the organic carbon content is relatively important for both the Pliocene dolomite (around 2\%) and the dolomitic mudstone in the Messinian below ( 1.91 to $4.66 \%$ ) samples. The content is low for the Miocene sample of Site $377(0.70 \%)$ and again higher for the Pliocene sample of Site 378 (3.96\%).

For the samples of Site 375 two groups of organic content, one above and one below 1 percent should be considered but their vertical distribution both in Tortonian and Serravallian series is irregular (Figure 3).

\section{Pyrolysis Assay and Organic Matter Characterization (Figures 3 and 4)}

The maximum of hydrocarbon production during pyrolysis assays was reached at relatively low temperatures in the $412^{\circ}$ to $444^{\circ} \mathrm{C}$ range for all the studied samples. This low temperatures range (Table 1) is characteristic of an immature stage of evolution.

The four samples in the Messinian evaporitic series of Site 374 (Figures 3, 4) can easily be distinguished from the others. They belong to good potential source rocks of petroleum, close to the reference type 2

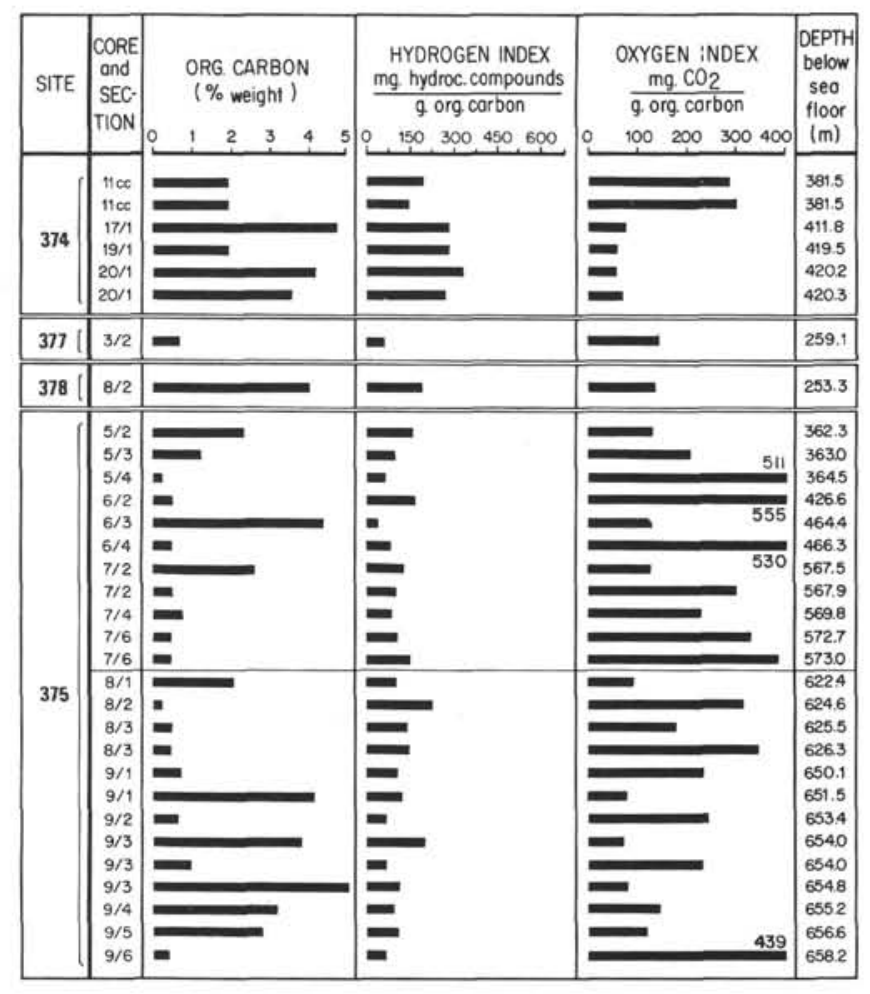

Figure 3. Pyrolysis assays. Geochemical logs (data related to organic carbon).
(Figure 4). Their hydrogen indexes of 265 to $335 \mathrm{mg}$ of hydrocarbon compounds related to $1 \mathrm{~g}$ of organic carbon can be compared with the $550-600$ values for immature material of type 2 which have the same low oxygen indexes.

All the other samples of Site 374 and other sites (Figures 3,4) reveal lower hydrogen indexes (less than 198 ) and higher oxygen indexes.

The samples of Site 375 show a wide dispersion of the oxygen index ( 75 to 600 ) but the variation falls to $75-250$ if we only consider the samples with more than $0.50 \%$ of organic carbon. They can be compared to the reference type 3 (Figure 4 ) but their relatively large variation of the oxygen index (75 to 250 ) cannot be explained by catagenetic effects.

The type 3 kerogens mainly correspond to higher plant detritus and humic continental matter. Their petroleum potential for oil is lower than for types 1 and 2 even if their petroleum yield could be of the same importance. The type 2 kerogens are common in marine sediments. They are rich in saturated $\mathrm{C}-\mathrm{H}$ groups and their potential for oil is good.

\section{Study of Chloroformic Extracts}

The six samples of Messinian to early Pliocene age from Site 374, the single sample from Site 378 plus the selected Serravallian samples from core 9 of Site 375 provided some extract ( 7 to $188 \mathrm{mg}$ ). The middle Miocene sample of Site 377 and the Tortonian samples from Site 375 , i.e., the separate samples from Core 5 and the two composite samples taken respectively from Cores 6 and 7 were devoid of extract (Table 2); the

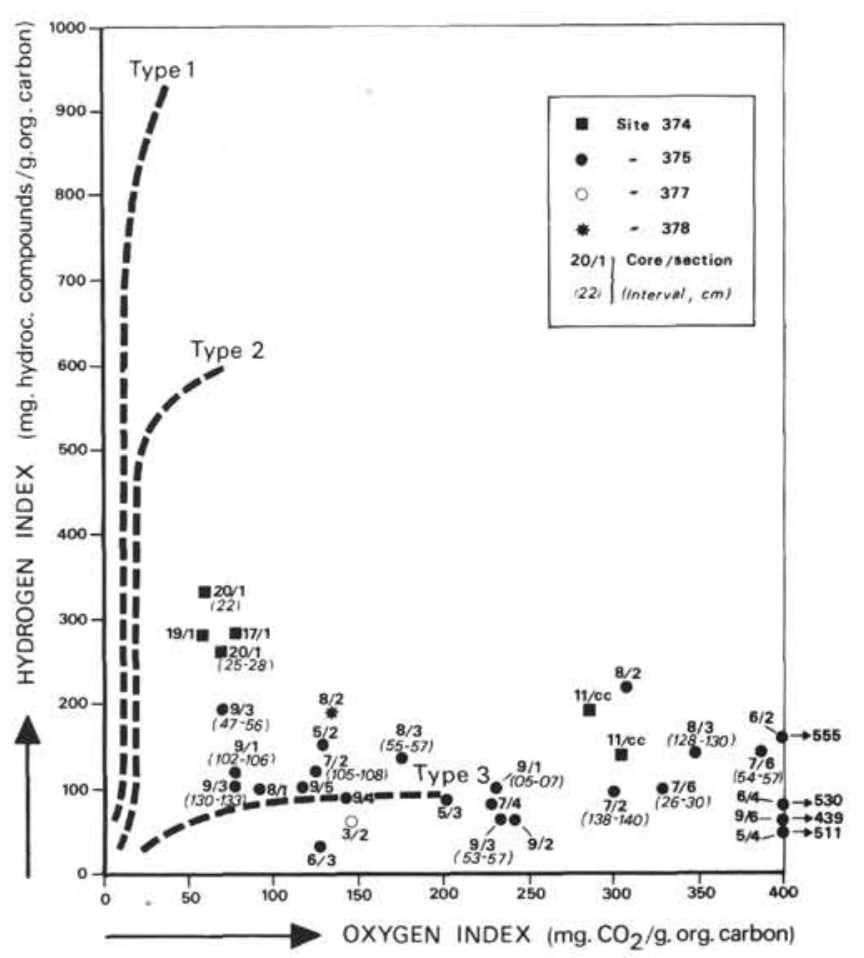

Figure 4. Pyrolysis assays. Hydrogen and oxygen indexes (data related to organic carbon). 
TABLE 2

Chloroformic Extracts

\begin{tabular}{|c|c|c|c|c|c|c|c|}
\hline \multirow[b]{3}{*}{$\begin{array}{c}\text { Sample } \\
\text { (Interval in } \mathrm{cm} \text { ) }\end{array}$} & \multirow{3}{*}{$\begin{array}{c}\text { Depth } \\
\text { Below } \\
\text { Sea } \\
\text { Floor } \\
(\mathrm{m})\end{array}$} & \multirow{3}{*}{$\begin{array}{c}\mathrm{HCCl}_{3} \\
\text { Extract } \\
\text { (Weight } \\
\text { mg) }\end{array}$} & \multirow{3}{*}{$\begin{array}{c}\text { Extract } \\
\text { to } \\
\text { Rock } \\
\text { Ratio } \\
\text { (Weight } \\
\% \text { ) }\end{array}$} & \multirow{3}{*}{$\begin{array}{c}\text { Extract } \\
\text { to } \\
\text { Organic } \\
\text { Ratio } \\
\text { Carbon } \\
\text { (Weight) }\end{array}$} & \multicolumn{3}{|c|}{$\begin{array}{c}\text { Thin Layer } \\
\text { Chromatography }\end{array}$} \\
\hline & & & & & \multirow{2}{*}{$\begin{array}{l}\text { NSO } \\
\text { Com- } \\
\text { pounds } \\
(\%)\end{array}$} & \multicolumn{2}{|c|}{$\begin{array}{c}\text { Hydro- } \\
\text { carbon } \\
\text { Fractions } \\
\end{array}$} \\
\hline & & & & & & $\begin{array}{l}\text { Aro } \\
(\%)\end{array}$ & $\begin{array}{l}\text { Sat. } \\
(\%)\end{array}$ \\
\hline $374-11, \mathrm{CC}$ & 381.5 & 6.9 & 0.07 & 0.033 & & & \\
\hline $11, \mathrm{CC}$ & 381.5 & 8.8 & 0.06 & 0.032 & & & \\
\hline $17-1,72-78$ & 411.8 & 188.3 & 1.24 & 0.222 & 83 & 12 & 5 \\
\hline $19-1,148-150$ & 419.5 & 21.5 & 0.18 & 0.081 & 72 & 13 & 15 \\
\hline $20-1,22$ & 420.2 & 72.1 & 0.52 & 0.117 & 85 & 7 & 8 \\
\hline $20-1,25-28$ & 420.3 & 38.5 & 0.49 & 0.118 & 84 & 7 & 9 \\
\hline $377-3-2,60-65$ & 259.1 & 0.0 & & & & & \\
\hline $378-8-2,26-32$ & 225.3 & 17.0 & 0.11 & 0.024 & 76 & 8 & 16 \\
\hline $375-5-2,82-88$ & 362.3 & 0.0 & & & & & \\
\hline $5-3,02-04$ & 363. & 0.0 & & & & & \\
\hline $5-4,150$ & 364.5 & 0.0 & & & & & \\
\hline $6-2,13-17$ & 462.6 & & & & & & \\
\hline $\begin{array}{c}\text { to } \\
6-4,85\end{array}$ & $\begin{array}{l}\text { to } \\
466.3\end{array}$ & & & & & & \\
\hline $\begin{array}{l}6-4,85-87 \\
7-2,105-108\end{array}$ & $\begin{array}{l}466.3 \\
567.5\end{array}$ & 0.0 & & & & & \\
\hline to & to & & & & & & \\
\hline $7-6,54-57$ & 573. & 0.0 & & & & & \\
\hline $9-1,102-106$ & 651.5 & 8.8 & 0.07 & 0.018 & 41 & 5 & 54 \\
\hline $9-3,47-56$ & 654. & 16.4 & 0.07 & 0.026 & 68 & 17 & 15 \\
\hline $9-3,130-133$ & 654.8 & 8.5 & 0.08 & 0.015 & 40 & 2 & 58 \\
\hline
\end{tabular}

latter samples of Cores 6 and 7 were grouped for studying the $\mathrm{HCCl}_{3}$ insoluble organic matter.

As the extract content was generally poor, fractionation was performed using the thin layer chromatography (TLC) method. At this point of study it should be noted, the two Pliocene dolomite samples of Site 374 were not fractionable because of insufficient material. The other extracts mainly correspond to NSO compounds and their hydrocarbon content is low (Table 2; Figures 5 and 6 ) as found for immature sediments.

The Messinian evaporite samples of Site 374 have a medium yield of extract ( 0.08 to 0.11 and 0.22 , related to organic carbon) and fractions obtained with TLC preparation revealed figures on thin layer preparations which were different from the usual hydrocarbon patterns. The same was found for the late Pliocene sample of Site 378. All these were controlled with gas chromatography (GC) analysis upon the unsaturated fractions. The chromatograms show peak distributions with retention times quite different from those known for normal alkanes and isoprenoids. From a thermal evolution point of view, the above characteristics would be typical of a diagenetic stage and not of a catagenetic one.

The three Serravallian samples selected for their organic carbon richness gave a low ratio of extract ( 0.015 to 0.026 versus organic carbon) but true hydrocarbon fractions were collected by TLC fractionation. They were confirmed with GC on the saturated fraction. On the chromatogram, besides the $C_{15}$ to $C_{31}$ normal alkanes and related isoprenoid distribution, a hump in the range of $\mathrm{C}_{29}-\mathrm{C}_{33}$ was present and did correspond mainly to unsaturated and saturated polycyclic compounds (Figure 7). The $\mathrm{N}$-alkanes distribution revealed an even-upon-odd predominance of $\mathrm{C}_{16^{-}}$ $\mathrm{C}_{18}$ range. Besides a high odd-upon-even carbon number predominance of n-alkanes from $\mathrm{C}_{21}$ or $\mathrm{C}_{23}$ to $\mathrm{C}_{31}$ was present (Figure 5). This predominance and the abundance of polycyclics in the $\mathrm{C}_{30}$ range would be

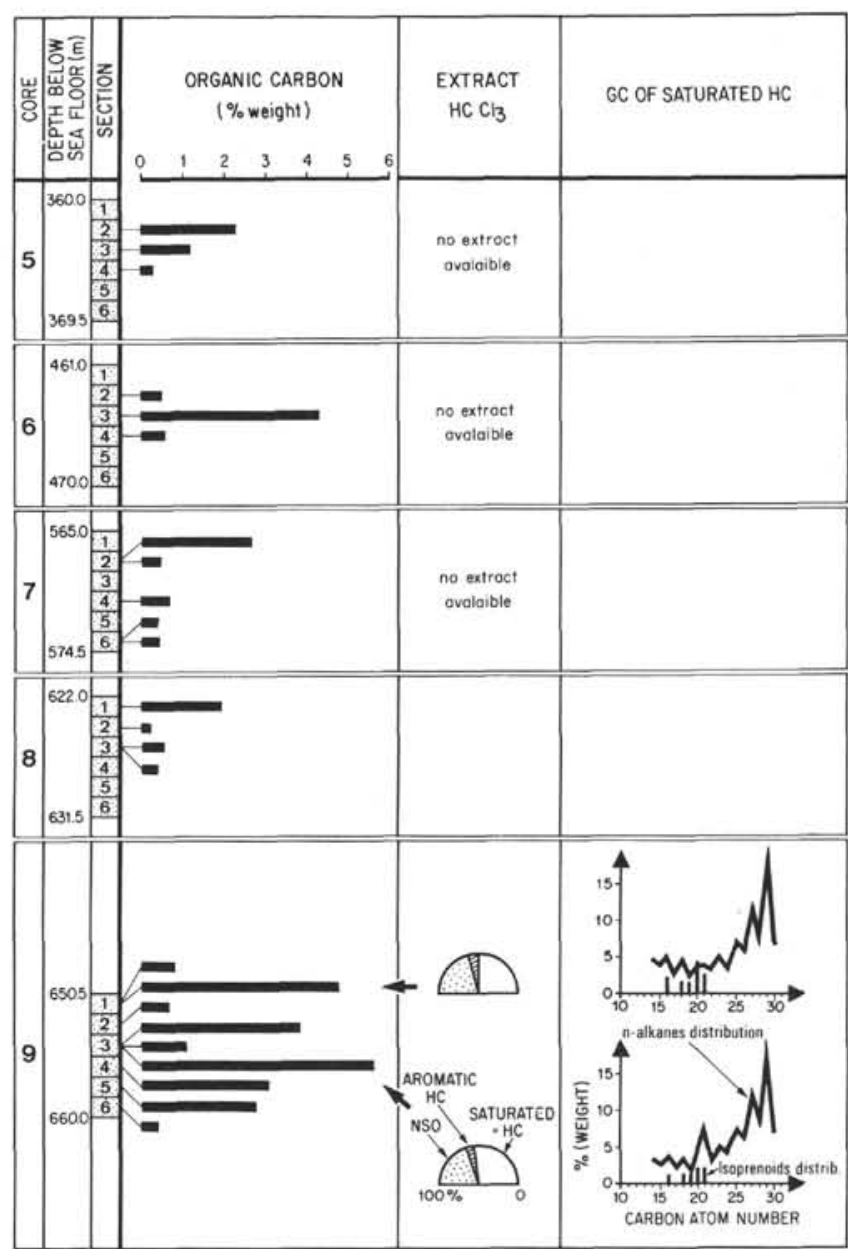

Figure 5. Site 375 organic carbon content. Gross composition of chloroformic extracts and distribution of normal alkanes and isoprenoids.

indicative of an early stage of catagenesis compared to the theoretically preceding stage of evolution, i.e., the late step of the diagenesis. The large proportion of $\mathrm{C}_{25}+$ odd normal alkanes would suggest an important contribution of higher plant waxes.

In the aromatic fraction, complex molecules with a high carbon number were largely present in the FID aromatic chromatogram (Figure 8 ) for a composite sample of Site 375 Core 9. They would suggest a low catagenesis. The very poor distribution of thiophenic compounds on the FPD chromatograms can also be mentioned.

\section{Study of Humic Compounds}

First, some samples had to be combined to supply enough material ( 50 to $100 \mathrm{~g}$ ) to perform humic and kerogen analysis. For Site 374 one sample was a combination of the samples of the evaporitic Messinian (Cores 17 to 20). For Site 375 two samples from Tortonian Cores 5 to 7 were combined and another combination gathered some of the samples of Serravallian age from Core 9 (Table 3 ).

The sample from evaporitic series of Site 374 had a very poor content of humic compounds corresponding to 2.4 percent total organic carbon. As the other 


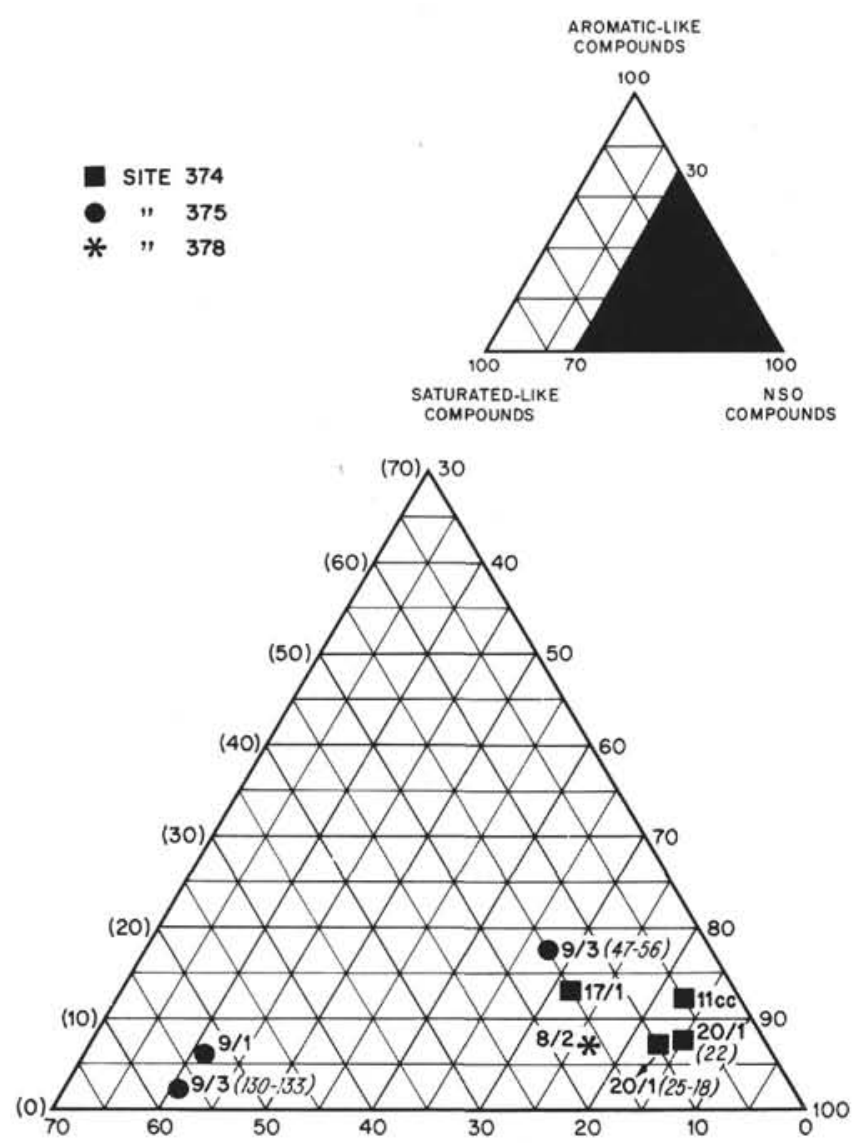

Figure 6. Cross composition of chloroformic extracts.
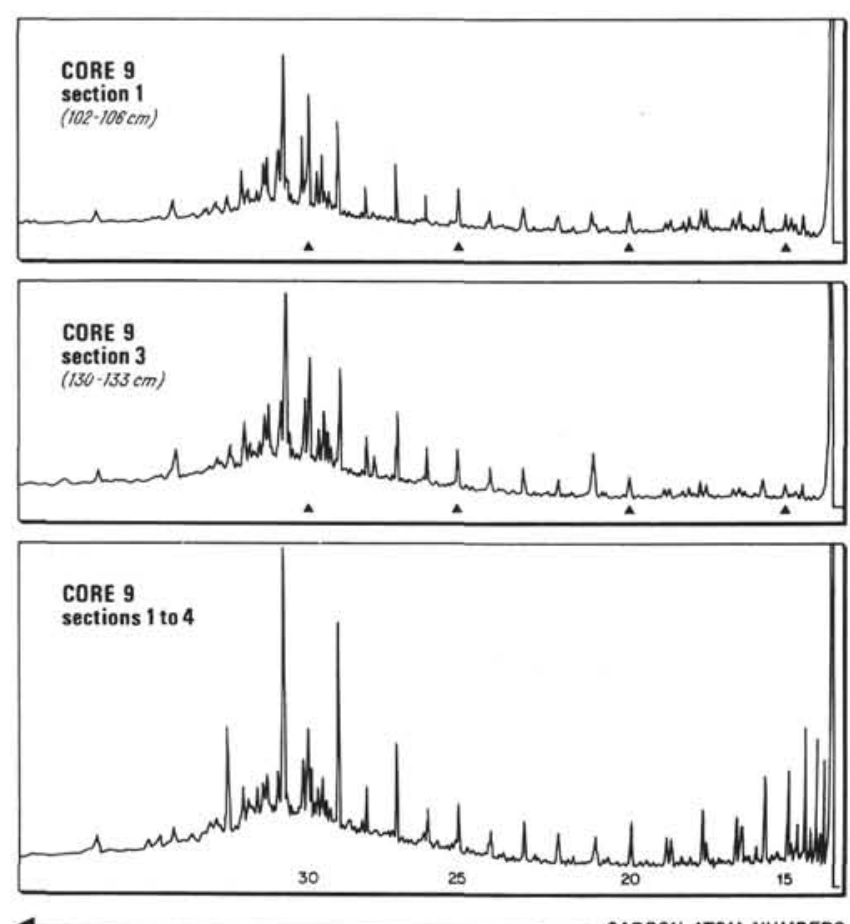

Figure 7. Site 375. Extracts. Gas chromatography of saturated fraction.

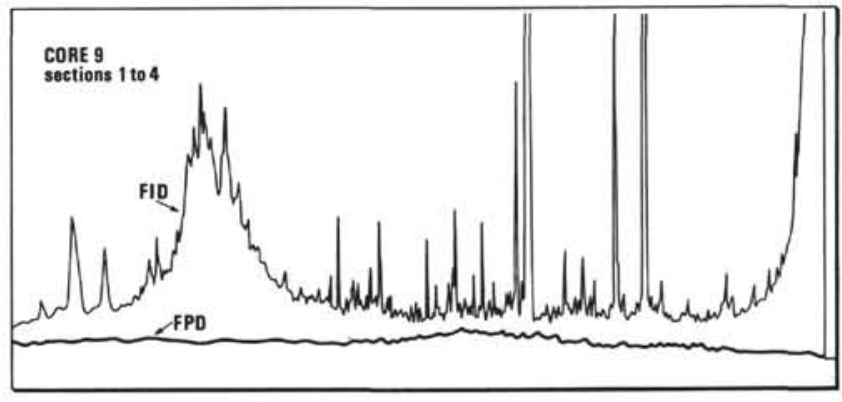

Figure 8. Site 375. Extracts. Gas chromatography of aromatic fraction (FID) and gas chromatography of thiophenic compounds (FPD).

TABLE 3

Humic Compounds and Carbon Organic Content

\begin{tabular}{|c|c|c|c|c|c|c|}
\hline \multirow[b]{2}{*}{$\begin{array}{c}\text { Sample } \\
\text { (Interval in cm) }\end{array}$} & \multirow[b]{2}{*}{$\begin{array}{l}\text { Depth } \\
\text { Below } \\
\text { Sea } \\
\text { Floor } \\
(\mathrm{m})\end{array}$} & \multirow[b]{2}{*}{$\begin{array}{c}\text { Total } \\
\text { Organic } \\
\text { Carbon } \\
\text { (Weight } \\
\% \text { ) }\end{array}$} & \multicolumn{3}{|c|}{$\begin{array}{c}\text { Carbon Content } \\
\text { (\% Total Organic Carbon) }\end{array}$} & \multirow[b]{2}{*}{$\begin{array}{l}\mathrm{FA} / \\
\mathrm{HA}\end{array}$} \\
\hline & & & $\begin{array}{l}\text { Humic } \\
\text { Com- } \\
\text { pounds } \\
\text { (FA } \\
+ \text { HA) }\end{array}$ & $\begin{array}{l}\text { Fulvic } \\
\text { Acids } \\
\text { (FA) }\end{array}$ & $\begin{array}{l}\text { Humic } \\
\text { Acids } \\
\text { (HA) }\end{array}$ & \\
\hline $\begin{array}{c}374-17-1,72-78 \\
\text { to } \\
20-1,25-28\end{array}$ & $\begin{array}{l}411.8 \\
\text { to } \\
420.3\end{array}$ & 4.09 & 2.42 & 0.97 & 1.45 & 0.67 \\
\hline $\begin{array}{c}375-5-2,82-88 \\
\text { to } \\
6-4,85-87\end{array}$ & $\begin{array}{l}362.3 \\
\text { to } \\
466.3\end{array}$ & 1.51 & 70.86 & 10.26 & 60.59 & 0.17 \\
\hline $7-2,105-108$ & $\begin{array}{c}567.5 \\
\text { to }\end{array}$ & 0.93 & 30.68 & 8.58 & 22.10 & 0.38 \\
\hline $\begin{array}{l}7-6,54-57 \\
9-1,05-07 \\
\text { to } \\
9-6,24-28\end{array}$ & $\begin{array}{l}573 . \\
650.5 \\
\text { to } \\
658.2\end{array}$ & 1.44 & 29.23 & 4.58 & 24.65 & 0.18 \\
\hline
\end{tabular}

characteristics such as pyrolysis and chloroformic extracts correspond to a very immature material the low content of humics could not be explained by an evolution effect. This low content must reflect an organic matter so well preserved during sedimentation and later that no humic process was engaged.

At Site 375 the contents of humic material in Tortonian samples were respectively 70 and 30 percent total organic carbon. It was close to 30 percent for the Serravallian sample but its fulvic acids (FA)-uponhumic-acids (HA) ratio was somewhat lower $(0.18$ against 0.38 ) than for the nearest Tortonian sample (Table 3). Such a high proportion of humic material in a moderate evolutionary stage (end of diagenesis, beginning of catagenesis) is typical of continental detrital organic matter (Huc et al., 1977). Thus-in the same manner as with the pyrolysis assays-humic compound data suggest a major continental contribution for the Tortonian and Serravallian analyzed samples. For the Serravallian, the chloroformic extract and the low FA/HA ratio would be indicative of a more advanced thermal evolution (early step of catagenesis?) than that of the other mentioned samples studied.

\section{Study of Kerogen}

The four samples selected for humic analysis were then used for a kerogen study. The elemental composition of their kerogen fraction (Table 4) allows to 
TABLE 4

Elemental Analysis of Kerogens

\begin{tabular}{|c|c|c|c|c|c|c|c|c|c|}
\hline \multirow[b]{2}{*}{$\begin{array}{c}\text { Samples } \\
\text { (Interval in } \mathrm{cm} \text { ) }\end{array}$} & \multirow{2}{*}{$\begin{array}{l}\text { Depth } \\
\text { Below } \\
\text { Sea } \\
\text { Floor } \\
\text { (m) }\end{array}$} & \multirow{2}{*}{\multicolumn{5}{|c|}{ Weight Per Cent, on Ash Free Basis }} & \multicolumn{2}{|c|}{ Atomic } & \multirow{2}{*}{$\begin{array}{c}\text { Ashes } \\
\text { (Weight } \\
\text { \%) }\end{array}$} \\
\hline & & & & & & & $\mathrm{H} / \mathrm{C}$ & $\begin{array}{c}\mathrm{O} / \mathrm{C} \\
\left(\times 10^{2}\right)\end{array}$ & \\
\hline $\begin{array}{c}374-17-1,72-78 \\
\text { to } \\
20-1,25-28\end{array}$ & $\begin{array}{l}411.8 \\
\text { to } \\
420.3\end{array}$ & 62.55 & 7.72 & 10.92 & 16.97 & 1.85 & 1.48 & 13.09 & 9.46 \\
\hline $\begin{array}{c}375-5-2,82-88 \\
\text { to } \\
6-4,85-87 \\
7-2,105-108\end{array}$ & $\begin{array}{l}362.3 \\
\text { to } \\
466.3 \\
567.5\end{array}$ & 41.31 & 5.37 & 25.06 & 27.06 & 1.19 & 1.56 & 45.50 & 50.05 \\
\hline $\begin{array}{l}\text { to } \\
7-6,54-57 \\
9-1,05-07 \\
\text { to } \\
9-6,24-28\end{array}$ & $\begin{array}{l}\text { to } \\
573 . \\
650.5 \\
\text { to } \\
658.2\end{array}$ & 63.66 & 6.47 & 22.46 & 4.55 & 2.85 & 1.22 & 26.46 & 35.94 \\
\hline
\end{tabular}

consider the $\mathrm{H} / \mathrm{C}$ and $\mathrm{O} / \mathrm{C}$ atomic ratios on a Van Krevelen diagram (Figure 9) in order to define the types of related organic matter (Tissot et al., 1974).

First the data of the Tortonian sample (Cores 5-6) from Site 375 should not be used because the elemental analysis revealed an abnormally high content of unexplained ashes (about $60 \%$ total ashes).

The sample from evaporitic series of Site 374 was located (Figure 9) halfway between the beginning of paths I and II. It would be compared with aliphaticrich kerogens of types I and II which were commonly found in the organic matter of marine environments.

The two other samples from Site 375 belong, respectively, to the Tortonian (Core 7) and the Serravallian (Core 9). In the latter a high ash content which was only issued from pyrite (58\%) could be noted. The two related kerogens had a lower $\mathrm{H} / \mathrm{C}$ and a higher $\mathrm{O} / \mathrm{C}$ atomic ratios (Figure 9) than the previous sample of Site 374. They were located in the area between the origin of paths II and III. So they would be composed of mixed continental and marine organic materials. As for the previous sample of Site 374 the vicinity of the origin of paths would be indicative of a low evolutionary range. However, it must be kept in mind that the kerogen of the two latter samples was not representative of the entire organic matter because humic compounds and hydrolysable fractions were also present.

\section{DISCUSSION AND CONCLUSIONS}

The organic matter encountered in the Messinian evaporitic levels of the Site 374 is of marine origin and these would represent good potential oil source rocks. Their low level of evolution is attested by pyrolysis indices and kerogen data. It cannot account for their poor content of humic compounds so that poorness must be related to an original absence of humic processes in evaporitic environments.

The organic content of all other samples studied from Sites 374, 377, 378, and 375 would mainly be derived from continental sources. They show, from pyrolysis and chloroformic extract data, the characteristics of poorly evolved or immature material. Continental input is confirmed for the Tortonian and Serra-

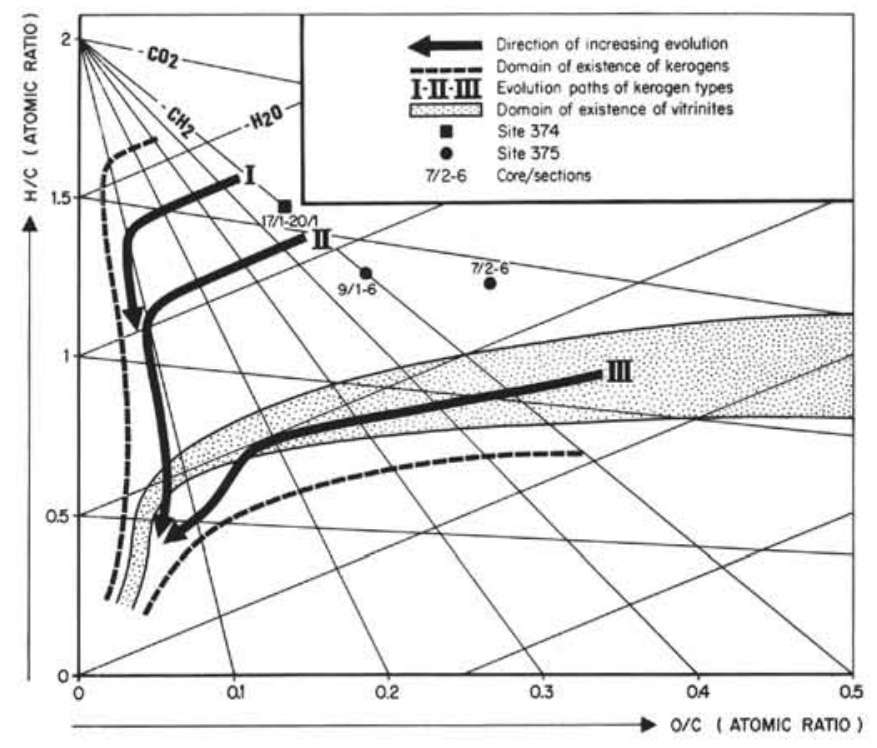

Figure 9. Kerogens. $\mathrm{H} / \mathrm{C}$ and $\mathrm{O} / \mathrm{C}$ diagram.

vallian samples studied from Site 375 by a high content of humic compounds although the continental material was less abundant in their kerogen fraction. Higher plant characteristics were found in the saturated fraction of the Serravallian extracts. These would represent a more advanced stage of evolution than revealed by the other extracts. Its stage would correspond to a late diagenesis or early catagenesis.

From these data, it appears that black sediments, even with a comparatively rich organic content may have a variety of origins. Some can be of a detrital origin as in most of the samples studied from the upper Miocene. The term "sapropel" should be avoided for that material and a stagnant environment would not necessarily be inferred.

\section{ACKOWLEDGMENTS}

The authors are indebted to Dr. J. M. Hunt, Woods Hole Oceanographic Institution, for comments and review of the present paper. 


\section{REFERENCES}

Durand, B., Espitalie, J., Nicaise, G., and Combaz, A., 1972. Etude de la matière organique insoluble (kérogène) des argiles du Toarcien du Bassin de Paris. Première partieEtude par les procédés optiques. Analyse élémentaire. Etude en microscopie et diffraction électroniques: Rev. Inst. Franç. Pétrole, v. 27, p. 865-884.

Durand, B. and Espitalie, J., 1973. Etude de la matière organique au cours de l'enfouissement des sédiments: C.R. Acad. Sci., Paris, v. 276, p. 2253-2256.

Espitalie, J., Durand, B., Roussel, J.C., Souron, C., 1973. Etude de la matière organique insoluble (kérogène) des argiles du Toarcien du Bassin de Paris. II-Etudes en spectrométrie infrarouge, en analyse thermique différentielle et en analyse thermogravimétrique: Rev. Inst. Franç. Pétrole, v. 28 , p. 37-66.

Espitalie, J., Laparte, J.-L., Madec, N., Marquis, F., Leplat, P., Paulet, J., and Bautefeu, A., 1977. Methode rapide de caracterisation des caches mères de leur potential pétrolier et de leur degré d'evolution: Rev. Inst. Franç Pétrole, v. 32 , p. $23-42$.
Huc, A. Y. and Durand, B., 1977. Occurrence and significance of humic acids in ancient sediments: Fuel, v. 56, p. 73-80.

Huc, A.Y., Roucache, J., Bernon, M., Caillet, G., Da Silva, M., 1977. Application de la chromatographie sur couche mince è l'étude quantitative et qualitative des extraits de roche et des huiles: Rev. Inst. Franç. Pétrole, v. 31, p. 6798.

Huc, A.Y., Durand, B., Monin, J.C., in press. Humic compounds and kerogens in cores from Black Sea sediments. Leg 42B-Sites 379A, 379B, and 380A. In Ross, D., Neprochnov, I., et al, Initial Reports of the Deep Sea Drilling Project, Volume 42B: (U.S. Government Printing Office), Washington

Robin, P.L., Rouxhet, P.G., Durand, B., in press. Caractérisation des kérogènes et de leur évolution par spectroscopie infra-rouge. In Advances in Organic Geochemistry: Madrid, 1975.

Tissot, B., Durand, B., Espitalie, J., Combaz, A., 1974. Influence of the nature and diagenesis of organic matter in the formation of petroleum: Am. Assoc. Petrol. Geol. Bull., v. 58, p. 499-506. 